\title{
Challenges in Implementing Extensive Reading (ER) Programs: Voices from English Teachers at Indonesian Secondary Schools
}

\author{
Anik N. Wulyani ${ }^{1 *}$, Utami Widiati ${ }^{2}$, Niamika El Khoiri ${ }^{3}$ \\ ${ }^{1-3}$ Universitas Negeri Malang, Jl. Semarang 5 Malang, East Java, Indonesia
}

\begin{abstract}
This article reports on the implementation of extensive reading (ER) among English teachers of secondary schools and the challenges they face as a part of their efforts in supporting the Indonesian government program of school literacy initiative (SLI). The data were obtained from an online survey to a group of English language teachers $(\mathrm{N}=22)$ from 22 different schools in one regency in East Java Province, Indonesia. The survey was then followed by a focused group discussion (FGD). The results show that in general, English teachers have a relatively good knowledge of ER as one way to support the success of SLI, but not all of them implement the programs due to such challenges as lack of support from the government and school administration, the overwhelming workload, and the unavailability of ready-to-use materials and activities. There is, therefore, a definite need for the government and school administration to support the implementation of SLI through ER by giving teachers and students necessary provisions, such as graded readers and structured ER activities.
\end{abstract}

Keywords: Extensive reading (ER), ER challenges, School Literacy Initiative, Secondary English teachers, Teacher voices.

\section{INTRODUCTION}

A growing body of literature has recognized the importance of extensive reading (ER) and that it is labeled with various names: pleasure reading, self-selected reading, free voluntary reading, or wide reading ( $\mathrm{Ng}$ et al., 2019). Recent trends in ER research have also led to a proliferation of studies on the effects of ER among students in second or foreign language classrooms and how ER helps students gain plethora of benefits around the world (Chang \& Renandya, 2017; Macalister, 2010; Mah \& Yeoh, 2016 \& Robb, 2002). Over the past two decades, most research on ER in second or foreign language classrooms has emphasized students' and teachers' views and perceptions about ER (Bui \& Macalister, 2021; Chang \& Renandya, 2017; Hadiyanto, 2019; Kim, 2019; Mohd Asraf \& Ahmad, 2003), the effects of ER on students' learning (Aka, 2019; Bui \& Macalister, 2021; Hadiyanto, 2019; Huffman, 2014; Iwahori, 2008; Kim, 2019; Yamashita, 2013) and ER in its current practice in Asian countries in secondary schools (Aka, 2019; Iwahori, 2008; Mohd Asraf \& Ahmad, 2003) and in tertiary education (Bui \& Macalister, 2021; Chang \& Renandya, 2017; Hadiyanto, 2019; Huffman, 2014; Kim, 2019).

A number of studies have postulated positive attitudes of students and teachers towards ER (Mohd Asraf \& Ahmad, 2003; Yamashita, 2013). Studies also show that L2 teachers held strong positive beliefs about the effectiveness of ER, but many of them were also challenged by numerous difficulties in implementing it. Some studies have indicated the causes of the difficulties, partly due to the facts that English teachers still feel unsettled to include ER in their limited teaching time, or that they perceived that their students would not learn through ER (Chang \& Renandya, 2017; Macalister, 2010 \& Mah \& Yeoh, 2016). Some other studies investigated students and/or teachers' perceptions of post-ER activities (Bui \& Macalister, 2021; Hadiyanto, 2019) and assessment practice in ER in the classrooms (Kim, 2019).

A considerable amount of literature has also been published on the effects of ER on learners' attitudes and learning achievement in several fields such as reading rate, reading fluency, and general English proficiency (Aka, 2019; Huffman, 2014; Iwahori, 2008; Mah \& Yeoh, 2016), four language skills (Cho \& Krashen, 2019), reading speed and comprehension (Chang, 2010; Macalister, 2010) and students' reading strategies such as guessing from contexts (Macalister, 2010). A more recent and comprehensive report concerning the effects of ER can be seen in a synthesis by $\mathrm{Ng}$

Corresponding Author e-mail: anik.nunuk.fs@um.ac.id https://orcid.org/0000-0002-4080-8288

How to cite this article: Wulyani AN, Widiati U, Khoiri NE (2022). Challenges in Implementing Extensive Reading (ER) Programs: Voices from English Teachers at Indonesian Secondary Schools. Pegem Journal of Education and Instruction, Vol. 12, No. 1, 2022, 74-83

Source of support: This article is based on a research study conducted in 2019 under the funding from the Directorate General for Research and Development Enhancement, Indonesian Ministry of Education and Culture, with the contract number of 10.3.82/UN32.14.1/LT/2020. We greatly appreciate the feedback provided by the anonymous reviewer.

Conflict of interest: None.

DOI: 10.47750/pegegog.12.01.08

Received: 29.08.2021

Accepted: 02.11.2021 Publication: 01.01.2022 
et al., (2019), which was inspired by two meta-analyses on ER by Nakanishi (2015) and Jeon and Day (2016). Ng et al., (2019) stated that the language skills investigated comprised reading rate and comprehension, vocabulary gains, writing ability, and grammar. These skills are closely linked to language literacy, one of the 21st century skills that need to be systematically developed at schools, including Indonesian schools.

In the Indonesian context, ER seems to have gained its popularity since the establishment of Indonesian Extensive Reading Association (IERA) in 2016 (Anandari \& Iswandari, 2019; Husna, 2019; Waring \& Husna, 2019). In the earlier year, in 2015, the Indonesian government launched a national program called School Literacy Initiative (SLI Gerakan Literasi Sekolah). This program was intended to improve Indonesian students' literacy level as stipulated in the 2013 National Curriculum. In regard to ER and SLI, it can be said that ER implementation by English teachers will positively contribute to the success of SLI implementation. A number of studies have been done by scholars,including the implementation of ER in secondary schools (Anandari \& Iswandari, 2019; Firda et al., 2018) and in tertiary Indonesian education settings (Hadiyanto, 2019; Husna, 2019).

The aforementioned studies indicate that while research has focused on learners' perceptions and views on the potential benefits of ER, there remain two aspects of ER about which relatively little is known, namely the implementation of ER at secondary schools by English language teachers and the challenges they face in ER implementation in the Indonesian context. Firda et al., (2018) found out that the behavioral attitudes towards ER among teachers were not yet positive, suggesting that they were still in doubt about whether to implement ER and also how to implement it. Therefore, there is a need for a study that can document the real challenges that secondary English teachers have in integrating ER into their English classes or in implementing ER in support of SLI implementation at the school level. In other words, this study aims to identify and explore the implementation of ER at secondary schools as well as to understand the prospects and challenges of implementing ER from the point of views of secondary English teachers. The results of this study are expected to give insights toward more effective and successful implementation of ER, which in the long run can contribute to the success of SLI implementation.

In short, to better understand the potentials of ER in improving high school students' literacy in the Indonesian context, we need to listen to the voices of Indonesian English language teachers because knowing the challenges and finding ways to address them will ensure the success of both programs, ER and SLI. Therefore, this study will more specifically uncover those aspects related to the implementation of ER among secondary English teachers in the context of supporting the national program SLI by responding to these research questions:

- To what extent are secondary English teachers familiar with the national program SLI?

- To what extent do they understand ER and its implementation?

- What challenges do they think they have in ER implementation?

- What do they think they can do to improve ER implementation?

\section{Method}

\section{Research Design}

This study was originally inspired by the empirical piece of evidence reported by Firda et al., (2018), revealing that in spite of their good understanding about ER and their willingness to implement ER, secondary English teachers in our context are still in doubt about implementing ER. Therefore, a case study is worth conducting to explore the real challenges secondary English teachers face when implementing ER in their classroom as well as school contexts so that possible causes of why many teachers still doubted how to implement ER can be untold. According to Yin (2008), case study research may be used to enlighten situations in which the intervention being evaluated does not yet have a clear set of outcomes. In the case of the present study, we did not yet have any empirical evidence regarding the problems English teachers have when integrating ER into their English classes or when integrating ER as a part of supporting the national program SLI. What this study was trying to uncover might serve as a follow-up to the study by Firda et al. (2018) regarding behavioral attitudes.

\section{Study Group}

This case study involved twenty-two EFL teachers of senior high schools and vocational high schools of a regency in East Java Province, Indonesia; ten teachers taught in public senior high schools, and the remaining taught at vocational high schools. They were members of secondary English teachers' forum in the regency. The teachers were of quite homogeneous backgrounds in terms of their academic qualification and their teaching contexts. Accessibility was our main reason for including those teachers in the study. They regularly hold a meeting as part of their professional development activities whereby university teachers like us are often involved as resource persons. In fact, the English teachers from the 22 schools were involved based on their willingness to participate in addition to meeting the criteria of the study in terms of geographical proximity to the place of the study, availability of time, and commitment to take part in the study in addition to easiness to access during the study (Dörnyei \& Csizér, 2011). The teachers' commitment was indeed essential as there were 
subsequent workshops with them as parts of our research activities on ER material development later. Prior to the research, all the teachers were given information about the study and they all agreed to participate in the study.

The present study aims to generate a description of the setting and phenomena being studied (Friedman, 2012), namely EFL teachers' ER practice in classes or at school, rather than testing an approach or examining the effectiveness of learning and teaching method. The case-study design has enabled us to deepen our understanding about teachers' voices in implementing ER as we were responding to the questions of why some secondary English teachers feel not confident to implement ER and how they think they can implement ER more effectively.

\section{Data Collection Instruments}

The data for the study were gathered through an open-ended questionnaire and focused group discussion (FGD). The questionnaire was employed to elicit data on the participants' demographic information as well as (1) their knowledge of SLI and the implementation of SLI at schools, (2) their knowledge of ER and its implementation at schools, (3) the challenges of ER implementation at schools, and (4) possible ways of dealing with the challenges. The questionnaire items were written in Bahasa Indonesia to ensure that the teachers understood the questions well and to ease them to elaborate detailed answers. The English equivalent of the original survey questionnaire is available in Appendix 1. The questionnaire was distributed online via Google Form.

The questionnaire items on ER materials, in particular, consisted of multiple-answer questions with the possibility for the respondents to choose more than one answer, seeking to find out teachers' understanding and perspective of the characteristics of ER materials. In this section, they were asked if the ER materials used: (1) have to support the implementation of relevant curriculum in Indonesian high schools, (2) are interesting for students, (3) contain newvocabulary, (4) encourage students to love reading, (5) are completed with comprehension questions, (6) are designed to grow students' curiosity, and (7) have a higher difficulty level than the students' competence level.

Following this data collection through the questionnaire, forum group discussion (FGD) sessions were conducted with the twenty-two ELT teachers participating to further investigate their ER-related and SLI-related activities. The FGD sessions were carried out in a face-to-face interaction format and were thus meant to clarify the answers provided by the participants during the online survey. The 22 teachers were invited to the FGD at their convenient time, agreed by all the teachers and the researchers. Such a combination of data forms as well as data collection techniques reflects a comprehensive way of data and data-technique checking, termed as triangulation (Creswell 2012; Neuman, 2014; Punch 2005; Yin, 2008).

\section{Data Analysis}

The data collected in the form of responses to the questionnaire and to the forum group discussion (FGD) sessions were then qualitatively analyzed to find out patterns of commonalities with regards to the teachers' understandings of ER as well as the prospects and challenges they were concerned with when implementing ER in their English classes or in the context of SLI program implementation. Reflecting the key features of a case study (Creswell 2012; Neuman, 2014; Punch 2005; Yin, 2008), the process of data analysis involved our assigning interpretations and meanings to the raw data collected through the questionnaire and the FGD. The process was thus far from rigid in a sense that we were not in control of the teachers' responses. Our observations from multiple angles made through the triangulation process of cross-checking the data from the questionnaire and those from the FGD sessions were intended to increase accuracy as well as to reduce the potential for bias yielded from engagement with the investigated phenomenon.

\section{FINDINGS}

The results of analyzing the EFL teachers' responses to the questionnaire items and the FGD are presented in the following subheadings, referring to the research questions.

\section{EFL Teachers' Familiarity with School Literacy Initiative (SLI) and Its Implementation}

The result of the online survey revealed that in general, the EFL teachers involved in the study were familiar with SLI. However, 2 out of 22 respondents (9.1\%) admitted that they had never heard of this program before. With regard to the implementation of the SLI program in schools, the data obtained from the survey showed that four schools did not implement this program in their institutions. The rest of the respondents $(\mathrm{N}=18)$ claimed that their schools had implemented the SLI program. Various answers were expressed by the 18 ELT teachers regarding the years when the SLI programs commenced. While the SLI program was established in 2015, some teachers believed that their schools have had the program since 2010, and some since 2013.

The activities that the schools did during the SLI range from a daily 15-minute reading of non-textbook materials prior to the lesson, a 10-minute reading of short stories or news articles before the class began, writing a review (of books) on Fridays, to reading a novel. The languages of the materials were either Indonesian or English. Other activities that the schools did were setting up a reading corner in every classroom, assigning students to read novels, and instructing students to read any material after school followed by some reflection. 
The results of the FGD confirmed the results of the survey regarding the implementation of SLI. While in general SLI was implemented on a daily basis, some schools had made several modifications. For example, one school assigned all students to do reading materials of their choice on Fridays, in which the activity lasted for 40 minutes during school time as stated by one of the respondents (Excerpt 1).

Our SLI program is done every Friday. The students read the novels that they like for 30 minutes. 10 minutes later, they write a synopsis in their GLS journal. Then, the synopsis is handed to and signed by the homeroom teacher. (Excerpt 1)

During the FGD, teachers whose schools did not implement the SLI lamented on the fact that their students did not want to read and that the school did not have a good collection of books to start with, as indicated in Excerpt 2.

Our school is in the outskirt of the city and most of our students come from the middle to low income families. They had to help the parents to make ends meet. Thus, they don't have time to study and they sometimes choose to sleep in the classroom. These students also have low proficiency as well as low reading interest. If we ask them to read other types of texts, other than the textbooks, they will say that they don't have the time and even worse is that the school library does not have sufficient book collection for the students to read. (Excerpt 2)

Both results of the survey and the FGD showed that while SLI was introduced in 2015, there were still teachers who were not familiar with the program, and some schools did not participate in this nation-wide initiative. English teachers can actually participate in the implementation of SLI through setting up ER programs.

\section{EFL Teachers' Understandings of ER and Its Implementation}

Regarding ER, 15 out of the 22 ELT teachers confirmed that they had used ER in their English classes. The data from this survey revealed three important key points regarding ER understanding and implementation. First, most teachers $(\mathrm{N}=20)$ could define ER. Only few of them $(\mathrm{N}=2)$ did not provide the definition of ER. Second, the teachers have varied understandings of what ER is. Third, the teachers whose schools did not implement SLI had different understandings of what ER is to those whose schools implemented SLI. The open-ended question on the teachers' understanding about ER and its definition showed that the EFL teachers whose schools implement SLI saw ER as a reading activity where students chose their reading materials based on their interests $(\mathrm{N}=5)$. The participating teachers also added that ER was reading for enjoyment $(\mathrm{N}=4)$. They additionally highlighted the fact that ER was done in a relaxing atmosphere outside the classroom/ at home $(\mathrm{N}=3)$, and its purpose was to increase students' knowledge and find information that the students needed $(\mathrm{N}=2)$. The key words used to define ER by the teachers whose schools implemented SLI are: not textbooks, fun, continuous, enjoyment, pleasure, and different from intensive reading. In contrast, the teachers whose schools did not implement SLI described ER as reading long and interesting texts and reading aiming at understanding the content of the passage, although they also used some relevant key words such as easy to understand and interest of the readers. These differences in defining ER showed that there are differences in teachers' understandings of what ER is between those teaching at schools that implemented SLI and those that did not.

Findings obtained from the FGD confirmed the findings drawn from the survey. The FGD showed that teachers whose schools did not implement SLI had different ideas of what ER is and what activities can be done to support ER. One teacher said:

If intensive (reading) comes from the word intensive or being serious, it means that the readers have to understand the content of the texts. However, if it is extensive reading, readers must choose the texts that they like and are suitable with their level of proficiency. (Excerpt 3)

Another teacher said that ER is:

...1. when readers are given texts based on their level of proficiency, 2. reading slowly, 3. readers are reading to get complete information ... (Excerpt 4 )

Excerpt 8 and 9 revealed that the teachers' understanding of ER still evolve around their partial comprehension as they mentioned, "get complete information and suitable with their level of proficiency".

Altogether, the findings from the survey and the FGD reveal that most teachers have sufficient knowledge of what ER is and what activities teachers and students can do during the program. However, the findings showed that not all of the teachers fully understand its concepts; they might not yet have the ideas on what activities can support ER program at schools. While the different perceptions towards the concepts of ER might be seen as isolated incidents, this evidence showed that even in educational institutions, each individual's understanding of the concept of ER differs and its contribution towards students' literacy level needs to be thoroughly improved.

As a part of exploring EFL teachers' understandings of ER, we elicited their opinions about ER materials, levels of language used in the materials, and the assessments used. Of the 15 teachers who admitted having implemented ER, most believed that ER materials should be interesting $(\mathrm{N}=14)$ and help nurture students' curiosity $(\mathrm{N}=14)$. These two points were followed by the need to have ER materials which can increase students' love for reading $(\mathrm{N}=13)$, build students' vocabulary mastery $(\mathrm{N}=10)$, and are in line with the curriculum $(\mathrm{N}=9)$. 
In addition, a few teachers argued that ER materials need to be accompanied with comprehension questions $(\mathrm{N}=5)$ and that the level of difficulty should be higher than the students' competence $(\mathrm{N}=5)$.

Regarding the level of the language used in ER materials, the survey question has three options, and the teachers can also choose more than one answer. The options are that the language level of the ER materials should be (1) higher than, (2) equal to, or (3) lower than students' competence levels. Twelve out of 15 ELT teachers believed that the ER materials should be equal to the levels of the students' competence. Eight out of these 15 teachers even viewed that the materials should be higher than the students' competence, and only four of them believed that they should be lower than the students' competence.

During the FGD sessions, some teachers who believed that ER materials should be "above the students' level" argued that if students were given easy materials, they would not learn anything new. This concern is arguably related to the previous discussion regarding assessment in ER, in which some teachers think of the need for providing comprehension test after the ER activities to ensure that the students did learn from the activities. In addition, some teachers argued that students needed to be given responsibility and clear instructions from ER activities; otherwise, they would not do the tasks as expected. One teacher elaborated on a comment made by her colleague when she wanted to set up an ER program at her school which required minimum level of assessment. However, throughout the session, some teachers clarified that "assessment" in ER did not have to be in the form of comprehension questions, but instead, students' opinions about the texts could also be asked, or whether there was a moral story to learn. All in all, the findings reveal that ELT teachers in the study had various ideas of what materials, levels of language used in the materials, and assessments are suitable for ER activities.

\section{EFL Teachers' Challenges in ER Implementation}

The data from the survey and FGD reveal several problems that challenge the implementation of ER at schools. Upon being asked using an open-ended question on the challenges of implementing ER at school, the respondents $(\mathrm{N}=22)$ wrote several different challenges, which include students' low reading interest and motivation to read $(\mathrm{N}=11)$, students' low vocabulary mastery in understanding the passages $(\mathrm{N}=11)$, the insufficiency of reading materials at the school libraries $(\mathrm{N}=10)$, and available time to do the activities $(\mathrm{N}=3)$. With regards to the most frequently mentioned issues, we obtained responses as reported by the teachers below.

Our challenges Are how to attract students' reading interest to read English stories; how to provide interesting reading materials; how to provide time to do the reading; and how to decide on follow-up activities after reading.

(Excerpt 5)

Students' low reading interest, especially texts written in English language, their English vocabulary mastery is limited and their dependency on the translation apps or their smart phones. (Excerpt 6)

We don't have sufficient resources at the school library and we don't have reading resources for students to read. (Excerpt 7)

The data from the FGD sessions imply several additional issues on the problems of ER implementation at schools as part of the SLI program. The first challenge, as claimed by most teachers $(\mathrm{N}=20)$, was the teachers' overwhelming workload. During the discussion, almost all teachers agreed that the workload, including the administrative work, is one of the biggest reasons that prevented them from using their creativity in various aspects of their teaching, including developing activities for the ER programs. Given the current workload, teachers often find it challenging enough to implement new, innovative strategies in their regular teaching and learning process, let alone to conduct programs like ER, which requires better time management.

Another problem in the implementation of ER program, as with the SLI program, is the minimum support from schools and the government $(\mathrm{N}=10)$. Throughout the discussion, one teacher claimed that ER program would not run effectively without full supports from various parties, especially from schools. Referring to the situation in her own school, she believed that it was impossible to assign students to read when the school did not provide any reading materials.

The third challenge faced by teachers in the implementation of ER program is rooted in the different perceptions and implementations. First, some schools in Indonesia, notably those that implement full day school (from $7 \mathrm{am}$ to $4 \mathrm{pm}$ ), do not allow teachers to give homework to students. Thus, if teachers assigned projects, tasks, or assignment related to ER activities, such as making a two-sentence summary, it is seen as assigning homework, thus crossing the boundaries set by the schools.

The fourth challenge is the different perceptions on the scopes of materials taught in ER program. Some schools believe that all of the activities done by students at schools should be directed to achieve the collective goals as stated in the curriculum. This policy has led some teachers to use only ER topics and materials that are related to the English syllabus in the curriculum. One teacher stated:

We can't teach subjects (like ER) if the end goals are not in line with the curriculum. Let's say one of the materials we use in ER program is reading a novel, and a student read an abridged novel entitled Oliver Twist. Is it related to the English text book or curriculum we are teaching? We actually want to have ER materials that are in line with the curriculum but we don't have such materials. (Excerpt 8) 
Considering all this evidence, it seems that the implementation of ER at secondary schools from the point of views of English language teachers is challenging due to several reasons, namely students' low interest and motivation, insufficiency of English reading resources available at schools, and teachers' working load.

\section{EFL Teachers' Strategies to Deal with the Challenges in ER Implementation}

Regarding the many challenges of the implementation of ER at secondary schools in the context of supporting the success of SLI, the teachers were requested to provide some suggestions. The survey reveals that the EFL teachers have several ideas to share. The most mentioned suggestion is relevant to the need for schools to support ER programs, such as providing an array of reading materials not only for students, but also for teachers, subscribing for some magazines or buying some novels, providing students with choices to access different reading media (soft or hard copy books), or having more interesting book collection at the school library or reading corner in each class.

The next suggestion is the needs of support from relevant institutions to boost the implementation of ER, which in the end, can also target the success of SLI. The supports the teachers suggested include facilitating the program by holding events such as literacy month, competitions or other relevant events, integrating ER within the teaching of various subjects at schools, having continuous ER activities in English classes, and providing rewards for students if necessary.

Overall, the results from the survey and FGD conclude that the implementation of ER program at schools is challenging, but there are several possible strategies teachers and schools have attempted to overcome the challenges.

\section{Discussion}

The findings of the study which have been presented in accordance with the four research questions are discussed here in relation to two key points that we have managed to identify: secondary English teachers' views about the implementation of SLI and ER at schools and their views about ER prospects and challenges.

\section{Implementation of SLI and ER at Secondary Schools}

With regards to School Literacy Initiative (SLI), the current study shows that the EFL teachers in our study have some knowledge of SLI and its importance. This finding is in line with Anandari and Iswandari's study (2019: 143) in which the respondents understood the importance of SLI and its role as a platform for ER implementation at school. One unanticipated finding was that some teachers do not yet know what SLI is. This finding was unexpected and suggests that regardless the fact that the SLI program was introduced in 2015, apparently not all teachers were familiar with the program; therefore, they might not have sufficient knowledge to use and implement the program at schools.

Regarding the concept of ER, most ELT teachers have good understandings, while a few of them still have vague ideas. In other words, while some teachers have good cognitive attitudes towards ER, some others are in need of further information of ER and the activities which can be done within ER programs. These findings reflect those of Firda et al., (2018) indicating that teachers have good and positive cognitive and affective attitudes of ER but not behavioral attitudes as reflected in their doubts in implementing it. The observed consistency of the Indonesian teachers of good understanding and attitude but moderate reservation might be caused by the partial support from school administrators (principals and staff). Previous studies showed that the success of SLI relies heavily on the management of SLI (Anandari \& Iswandari, 2019; Lastiningsih et.al., 2017). Without the supports from the school administrators, motivation is lacking, and ER thus runs unsystematically.

Despite teachers' familiarity with ER, a distinct issue with teachers' understandings in relation to the use of assessments in ER is also apparent. This present study showed that many teachers found it difficult to distance themselves from the "supervising" role when it came to ER in real practice. While the finding was not expected, the fact that the teachers still feel the urge to provide students with comprehension questions in the end of the ER activities show that they are not familiar with the different types of assessment ER should offer to the students. The aim of reading extensively is building the love of reading (Day et al., 1998). Thus, giving comprehension questions are not recommended as it may take away the fun of the reading.

Together these findings suggest that some teachers clearly need to redefine the word "learning" in this context, as one of the goals of ER is to make students "enjoy" reading, and that the students will also "learn" something along the way. Therefore, the level of language for the materials should be adjusted to students' proficiency level. Ideally, the ER materials prepared should not be too difficult as to discourage students from sustaining reading activities. However, the case will be different if students feel the need to challenge themselves with more challenging materials. Provided that students do enjoy the process of the given ER activities teachers then need to encourage students and give support whenever possible.

\section{Prospects and Challenges of SLI and ER Programs}

Previous studies showed that SLI and ER play important roles in the realization of literacy-rich school enviroments (Anandari \& Iswandari, 2019; Durriyah, 2019; Firda et al., 2018; Ng et al., 2019). However, these studies also showed that 
the initiatives were not without challenges. The findings of our study revealed that the implementation of SLI and ER at schools is promising as well as challenging. The study found that teachers' cognitive attitude toward SLI and ER is positive. Most of the participating teachers were familiar with SLI and were able to explain what ER was and what benefits ER had. This finding is in line with the studies conducted by Chang and Renandya (2017) and Firda et al., (2018). The findings of the present study also confirm the study done by (Macalister, 2010). He called the positive cognition of ER as "a favourable predisposition among many teachers towards ER” (p. 72), where teachers did their best to encourage students to read and even welcome opportunities to provide more chances for ER in their classrooms. The present study also observes the ELT teachers' spirit to utilize ER to help students to build the love of reading and improve their English vocabulary. In the end, these predispositions are expected to improve the students' English proficiency.

In other words, the present study shows that numerous teachers have extended their efforts to understand and implement ER as the realization of SLI program. Some schools also try to implement this program by establishing a taskforce specifically assigned to manage the SLI programs in their schools. This taskforce involves school administrators, teachers, as well as students. This finding strongly supports the work of Firda et al., (2018) and Macalister (2010), which state that ER integration needs to involve all school members, including school managers, administrators, and principals.

Several issues challenge the implementation of SLI and ER programs at school levels. First, the implementation of SLI elsewhere in Indonesia also faces similar issues in which a 15-minutes activity in the beginning of the class is simply not sufficient for students to read anything (Kurniawan, Sriasih, \& Nurjaya, 2017), and special taskforce is needed to help the initiatives to run well and to make the program successful (Nopilda \& Kristiawan, 2018; Yulianto, Jannah, \& Nurhidayah, 2018). These results may be explained by the fact that a 15-minute reading activity before class seems to be too far away from reaching anything. While the idea of a 15-minutes reading activity is feasible, the fact that it is not integrated into language learning activities, the results of the 15-minute reading activity is debatable.

The second issue is students' lack of motivation. Kurniawan et al. (2019) claim that students' low motivation takes place as one of the problems in implementing ER programs. The present study further confirms Kurniawan et. al.'s (2019) study as students' lack of motivation is also apparent as informed by the participating teachers. In their study, the teachers agreed that the lack of students' motivation was a challenge during the implementation of the ER program. This finding is interesting as students' low motivation in reading was initially the main purpose as to why extensive reading was introduced.
The third issue faced by teachers is having limited time to create interesting ER activities for their students, which can actually be solved provided that students have access to readymade ER activities that are further adjusted to teachers' various situations. However, the limited availability of such materials poses the next challenge for teachers, especially those who are not familiar with ER and ER activity/program development.

With regards to the issue of perceiving ER as additional homework for students, this study confirms the idea that ER is associated as extra tasks for students (Firda, et.al., 2018). The post-reading activities are sometimes counted as "homework" by some school administration, which results in the ER getting labeled as "illegal" activity. Moreover, ER is not always seen as a favorite among teachers or schools which implemented a school policy that does not allow students to bring schoolwork home. This policy is based on the consideration that students should not be given extra burden at home after spending the whole day studying at schools.

The issues on lack of support from schools and the government are both understandable and debatable. It is understandable as ER program requires an extensive number of books which also leads to financial implications for schools (Macalister, 2008: 71) and the government, which in the Indonesian context, is under the Ministry of Education and Culture. If the issue is not well handled as schools do not have the financial support to facilitate ER programs, teachers will not be able to provide students with the best experience. This also affects the second principle of ER as it demands a variety of reading materials on a wide range of topics (Day \& Bramford, 2002). The issue is debatable as the Indonesian government has taken some efforts to ensure that the program can run well by providing a website with some reading materials (Macalister, 2010; Yamashita, 2013) and also manuals on how to implement ER and be successful in supporting ER (see https://gln. kemdikbud.go.id/glnsite/wp-content/uploads/2019/04/6.-SeriManual-GLS Membaca-Untuk-Kesenangan.pdf).

With regard to government's support in the implementation of ER program, Indonesia might learn from other countries with more established literacy program. The NSW government of Australia, for example, has an ER initiative called "Premier's Reading Challenges". In their website https://online.det.nsw. edu.au/prc/home.html, it is stated that the challenge "aims to encourage a love of reading for leisure and pleasure in students, as well as to enable them to experience quality literature". The website contains very detailed information on the rules of the challenge, and at the end of the year, those who are successful in completing the challenge will get a certificate signed by NSW Premier. This is a good example of how a government can play a significant role in supporting a program to make sure goals are achieved. In a wider context, such support needs to come not only from schools, but also from the government. It was not enough for the government to merely set up a program and 
encourage schools to participate without providing necessary supports, especially in schools whose students came from mid-low socio-economic backgrounds.

In other words, consistent with the previous literature, this study discovers that teachers have good and positive understandings of ER, but they find some issues on ways to incorporate ER inside and outside the classroom due to their varied understandings of the definition and implementation practices (Firda et al., 2018; Macalister, 2010). These results are likely to be related to the hurdles particularly faced by English teachers in the Asian context (Robb, 2002) who perceived that their students did not learn through ER. Teachers seem to be hesitant with the idea of ER as the results of the students' learning process within ER programs are not tangible and conveniently assessed.

During the FGD, some teachers admitted that their schools have the get-it-done attitude in relation to SLI program. This situation was caused by several factors, for example, the limited variation of reading materials available at school, limited time available and teachers' overwhelming workload which prevent them from conducting the program in a more organized way. As a result, some schools sometimes assign students to bring their own materials during the 15 minutes reading activity. However, with no clear expectation from the activity, many students ended up talking to each other and the 15 minutes was over before they knew it.

\section{Conclusion}

This study set out to investigate the implementation of ER at secondary schools with regards to their efforts to take part in the success of the SLI program launched by the Indonesian government. The aim of the present research was to understand the issues and challenges faced by the English language teachers in implementing the program at their schools.

This study has identified three key findings. First, SLI has been part of many school's initiatives to have literacy-rich school environment. Second, ER has been used by teachers in their classrooms as one of the activities to implement SLI at schools. Third, the implementation of ER as a way to support SLI is favorable, but it is not without any hindrances. The study also highlights the importance of school administrators' supports to have effective and successful ER programs at secondary schools. The assistance from the principals as well as the school administrative staff plays very crucial roles to ensure that the SLI and ER run well.

Programs like ER do not normally receive sufficient support, and teachers find it difficult generating ideas on running this program or conducting suitable activities to serve the purposes of ER. Thus, without the necessary support, it will be very challenging as well as daunting for the teachers to realize ER program at schools. Another stage necessary for an ER program to run well is the availability of books or reading materials at schools. When teachers are engulfed in their main responsibilities, it is quite understandable that they require ready-to-use ER activities or programs which will help them save the burden of having to find fresh ideas on their own. However, as some teachers have pointed out, such materials are neither widely available nor accessible.

The issues related to challenges revealed from the study need to be solved in a more comprehensive manner. All the stakeholders in the educational sector need to work together so that the ER program will have some meaningful impacts on students' attitudes towards reading. It is certainly not enough to set up a program, no matter how sophisticated it is, without giving adequate support along the way. In terms of the challenges in the implementation of this program, further research needs to be conducted to make sure that voices coming from parents, students, school administrators as well as the government are heard. Such approach is necessary as a mean to solve the problem and not as a chance to point fingers when something does not go as expected.

In brief, Indonesian government's decision to launch SLI nationwide is a positive sign which shows both the acknowledgment of students' low literacy level in the country, as well as the willingness to solve the problem. At the implementation level, however, EFL teachers who are trying to carry out ER as one way to support SLI success face a number of challenges such as supports from the government and school administration, the overwhelming workload, and the unavailability of ready-to-use materials and activities. There are also problems which are rooted from different perceptions of ER between teachers and school principals, while the teachers themselves also have various understandings about the definition of ER.

\section{Suggestions}

The issue regarding the scarcity of books and reading materials for students and ready to use ER activities for teachers is quite persistent. Thus, it is suggested that schools provide more graded English reading materials as they benefit students' vocabulary mastery and English proficiency. The teacher association is also suggested to work with relevant institutions, such as teaching training institutions, to create post-reading activities to support a continuous and regular SLI and ER programs. With regard to future research, researchers could usefully explore a broader range of English language teachers to shed more lights on how to handle the challenges and reveal best practices of ER around the country in particular, or around the world in general.

\section{Limitations}

Being limited to the unideal recruitment process of the participants, the study may lack the ability to generalize its findings to a broader group of English language teacher 
society outside the current research site. Another limitation of the study is related to the fact that it focuses primarily on teachers' roles and voices in the implementation of ER, while in reality, the success of such program is determined by a collective work of all stakeholders. In spite of its limitations, the study certainly adds to our understanding that challenges of ER implementation have to be tackled; prospects of ER and improving students' literacy skills should thrive and continue moving forward.

\section{References}

Aka, N. (2019). Reading performance of Japanese high school learners following a one-year extensive reading program. Reading in a Foreign Language, 31(1), 1-18. https://doi.org/10125/66747

Anandari, C. L., \& Iswandari, Y. A. (2019). Extensive reading in Indonesian schools: A successful story. TEFLIN Journal, 30(2), 137-152. https://doi.org/10.15639/teflinjournal.v30i2/137-152

Bui, T., \& Macalister, J. (2021). Online extensive reading in an EFL context: Investigating reading fluency and perceptions. Reading in a Foreign Language, 33(1), 1-29. http://hdl.handle. net/10125/67391

Chang, A. C.-S., \& Renandya, W. A. (2017). Current practice of extensive reading in Asia: Teachers' perceptions. The Reading Matrix: An International Online Journal, 17(1), 40-58.

Cho, K.S., \& Krashen, S. (2019). Pleasure reading in a foreign language and competence in speaking, listening, reading and writing. TEFLIN Journal, 30(2), 231-236. https://doi.org/10.15639/ teflinjournal.v30i2/231-236

Creswell, J.W. (2012). Educational research: Planning, conducting, and evaluating quantitative and qualitative Research. Pearson.

Day, R. R., Bamford, J., Renandya, W. A., Jacobs, G. M., \& Yu, V. W.-S. (1998). Extensive reading in the second language classroom. RELC Journal, 29(2), 187-191. https://doi. org/10.1177/003368829802900211

Dörnyei, Z., \& Csizér, K. (2011). How to design and analyze surveys in second language acquisition research. In A. Mackey \& S. M. Gass (Eds.), Research Methods in Second Language Acquisition (pp. 74-94). John Wiley \& Sons, Ltd. https://doi. org/10.1002/9781444347340.ch5

Durriyah, T. L. (2019). "If we don't include literature, where do we teach our students from?" An effort to introduce children's literature to Indonesian preservice teachers. Reading Horizons: A Journal of Literacy and Language Arts, 58(3). Retrieved from https://scholarworks.wmich.edu/reading_horizons/vol58/ iss $3 / 4$

Firda, I. D. L., Widiati, U., Laksmi, E. D., \& Hayati, N. (2018). Attitudes toward extensive reading among English teachers of senior high schools. Jurnal Ilmu Pendidikan, 24(1), 1-9. https:// doi.org/10.17977/um048v24ilp1-9

Friedman, D. A. (2012). How to collect and analyze qualitative data. In A. Mackey \& S. M. Gass (Eds.), Research Methods in Second Language Acquisition (pp. 180-200). John Wiley \& Sons, Ltd. https://doi.org/10.1002/9781444347340.ch10/summary

Hadiyanto, A. K. (2019). Students' collaborative story writing project in an extensive reading program. TEFLIN Journal, 30(2), 197-211. https://doi.org/10.15639/teflinjournal.v30i2/ $197-211$
Huffman, J. (2014). Reading rate gains during a one-semester extensive reading course. Reading in a Foreign Language, 26(2), 17-33.

Husna, N. (2019). Developing students critical thinking through an integrated extensive reading program. TEFLIN Journal, 30(2), 212-230. https://doi.org/10.15639/teflinjournal.v30i2/212-230

Iwahori, Y. (2008). Developing reading fluency: A study of extensive reading in EFL. Reading in a Foreign Language, 20(1), 20-91.

Jeon, E.-Y., \& Day, R. R. (2016). The effectiveness of ER on reading proficiency: A meta-analysis. Reading in a Foreign Language, 28(2), 246-265.

Kim, M. (2019). The perceptions of students and teachers on the practice of assessment in extensive reading. English Teaching, 74(4), 179-203. https://doi.org/10.15858/engtea.74.4.201912.179

Lastiningsih, N., Mutohir, T. C., Riyanto, Y., \& Siswono, T. Y. E. (2017). Management of the school literacy movement (SLM) programme in Indonesian junior secondary schools. World Transactions on Engineering and Technology in Education, 15(4), 384-389.

Macalister, J. (2010). Investigating teacher attitudes to extensive reading practices in Higher Education: Why isn't everyone doing it? RELC Journal, 41(1), 59-75. https://doi. org $/ 10.1177 / 0033688210362609$

Mah, A. S.-H., \& Yeoh, M. (2016). The wide and wild world of words: Interview with Averil Coxhead. RELC Journal, 47, 263-268. https://doi.org/10.1177/0033688216655926

Mohd Asraf, R., \& Ahmad, I. S. (2003). Promoting English language development and the reading habit among students in rural schools through the Guided Extensive Reading program. Reading in a Foreign Language, 15(2), 83-102.

Ivonne Ramírez; Sagrario Pérez de la Cruz; Carolina Maldonado. «Continuous transdisciplinary education in order to detect neurodevelopment disorders among five years old». Journal for Educators, Teachers and Trainers, 10, 2, 2019,

Nakanishi, T. (2015). A meta-analysis of extensive reading research. TESOL Quarterly, 49(1), 287-295. https://doi.org/10.1002/ tesq. 157

Ng, Q. R., Renandya, W. A., \& Chong, M. Y. C. (2019). Extensive reading: Theory, research, and implementation. TEFLIN Journal, 30(2), 171-186. https://doi.org/10.15639/teflinjournal. v30i2/171-186

Neuman, W.L. (2014). Social research methods: Qualitative and quantitative approaches. Pearson Education Limited.

Punch, K.F. (2005). Introduction to social research: Quantitative and qualitative approaches. Sage Publications.

Robb, T. (2002). Extensive reading in an Asian context-An alternative view. Reading in a Foreign Language, 14(2), 146-147.

Waring, R., \& Husna, N. (2019). Expectations and experiences of Indonesian teachers who have, and have not, done extensive reading. TEFLIN Journal, 30(2), 153-170. https://doi. org/10.15639/teflinjournal.v30i2/153-170

Yamashita, J. (2013). Effects of extensive reading on reading attitudes in a foreign language. Reading in a Foreign Language, 25(2), 248-263.

Yin, R.K. (2008). Case study research: Design and methods. Thousand Oaks: Sage Publications.

Yulianto, B., Jannah, F., Nurhidayah, M., \& Asteria, P. (2018). The implementation of school literacy movement in elementary school. Advances in Social Science, Education and Humanities Research, 73, 43-46. https://doi.org/10.2991/icei-17.2018.12 


\section{Appendix}

English Equivalent of the Original Survey

Do you know School Literacy Initiative/SLI? (If you don't know, go to number 6)

Does your school where you are teaching implement SLI?

Since when did your school implement the SLI program?

What activities do you usually do in the SLI?

What do you know about Extensive Reading (ER) program? Please write in three sentences.

When teaching English, do you do ER activities? If yes, in what form? If not, why not?

What differentiate Extensive Reading from Intensive Reading? Please write three differences.

In your opinion, what materials are suitable for ER activities (you may choose more than one answer):

support the implementation of curriculum

are interesting for students

include new vocabulary items

allow students to love reading are completed with comprehension questions

nurture students' curiosity

are higher than the students' competence level in difficulty

In your opinion, the level of the English used in the ER materials should be:

slightly above the level of the student's competence so that they can learn new things

the same level with the student's competence so that they don't face difficulties when reading texts

lower than the level of the student's competence so that they feel comfortable when reading

After the students' finish their ER activities, the teachers:

need to ensure if the students understand what they read by providing them with comprehension questions of the texts

don't need to check the students'comperhension of the texts

What are the challenges that you face when you are implementing ER at your school? If you have not implemented ER at your school, what are the challenges that you might face?

Do you have any suggestions with regards to the implementation of ER at schools? 